\title{
The Effect of Vertical and Horizontal Trust on Voluntary Tax Compliance (An Experimental Study)
}

\author{
Ivonne Helena Putong \\ Universitas Airlangga \\ Surabaya, Indonesia \\ Politeknik Negeri Manado \\ Manado, Indonesia \\ ivonnehelen@yahoo.com
}

\author{
Arsono Laksmana \\ Universitas Airlangga \\ Surabaya, Indonesia
}

\author{
I Made Narsa \\ Universitas Airlangga \\ Surabaya, Indonesia
}

\begin{abstract}
Every country, with a voluntary tax collection system, should consider the potential tax evasion. The economics of crime approach which is expected to increase tax compliance is still constrained by considerable amount of administrative costs. Trust-based regulation can reduce the social costs for taxpayers and tax authorities. This study examines the effect of the trust of taxpayers to the tax authority and other taxpayers on voluntary tax compliance in laboratory experiments. The subject of this study is MSMEs business people who have already got Tax ID Number (TIN). Factorial design used is $2 \times 2$ using tools such as booklets, videos and storyboards. The results of this study provide empirical evidence that supports the main effect of vertical trust and horizontal trust on tax compliance. Hypothesis 3 predicts the effect of the interaction between the trust to tax authority and the trust to other taxpayers on the amount of income reported. However, the results of the analysis show no interaction, which means that fair treatment from the authorities is not a stimulant for taxpayers to contribute to pay taxes.
\end{abstract}

Keywords: Vertical Trust, Horizontal Trust, Tax Compliance, Tax Authority

\section{I . INTRODUCTION}

Indonesia has adopted self assessment system in the implementation of its taxation. Self assessment system is the mandate of Article 2 of General Provisions of Taxation (KUP). In this system, a taxpayer is given the power and opportunity to enroll and obtain a Tax Numbers (NPWP) and is confirmed as a Taxable Persons for VAT Purposes (PKP), to calculate the tax payable independently, to calculate the taxes that have been deducted and levied by other parties, to deposit additional taxes payable independently, and to report his tax return (SPT) on his own awareness. The taxes paid by the taxpayer shall be deemed true until the government can prove it wrong.

The impact of such a system is that the supervision on tax compliance becomes an urgent matter that must be considered by the Directorate General of Taxation. This is because the taxpayers are given full authority to carry out or not to carry out their rights and obligations. This system highly relies on the taxpayers' awareness, so it must be supported by clear, fair and transparent rules and simple administrative procedures. In fact, tax evasion behavior tends to be part of the self assessment system.

Madeo et. al[1] explain that the process of self-assessment system in tax reporting is based on the duty of all taxpayers to fill out and report their income on the tax returns properly. In line with the implementation of self-assessment, the taxpayers are expected to reach the level of voluntary tax compliance. Voluntary tax compliance refers to the compliance of the taxpayers to report tax on actual conditions.

In general, people think of tax as a tribute, so it is deemed burdensome. They have less confidence in the existence of tax and know nothing about what and how tax is. As a result, the cost of compliance is high because it requires intensive audits and increased sanctions. Although tax revenue has increased every year, but Indonesia still faces some problems. First, the tax ratio is still relatively low compared to other countries. Second, the tax reporting ratio is very low, especially related to the ratio between the number of taxpayers who contributes to taxes and the number of registered taxpayers. Thirth, the realization of the revenue of all kinds of taxes is still below its potential.

Basically, nobody likes to pay taxes. The most popular instrument to force people to pay taxes is the implementation of prevention policies. According to the theory of neoclassical economic standard, strict audit enforcement and fines determine the level of tax evasion[2]. Tax compliance will increase in accordance with an increase in audits and sanctions. However, the increase in compliance is not significant[3]. Subsequent research reveals that compliance cannot be explained entirely by purely financial considerations, but mainly generated by the level of enforcement[4]. Tax compliance becomes higher due to psychological factors such as: increased understanding of tax ethics[5], friendly approach[6], or when a taxpayer receives in 
return from government in the form of public facilities funded from tax payments[7] and other social factors.

Trust is an important factor that can overcome the crisis and the difficulties between the tax authorities and the taxpayers. Besides, it is also an important asset in building long-term relationships.

Trust is divided into vertical trust and horizontal trust. Vertical trust is the trust of the taxpayer to the tax authorities, while horizontal trust is the trust of the taxpayer to other taxpayers. The purpose of this study is to find out empirical evidence of the effect of trust factor on voluntary tax compliance. Voluntary tax compliance is necessary to understand because it can reduce the cost of compliance[8].

Vertical trust is influenced by the treatment provided by the tax authorities to taxpayers. If the procedures of tax administration are well communicated to the taxpayers, the motivation to comply with the tax will be higher. The tax authorities also have to avoid being inferior, for example, by treating the taxpayers like "cops and robbers", causing the taxpayers to evade taxes[9]. Procedural fairness shows how much the public perception on the level of fairness and justice of the procedures performed by the authority in decisionmaking. The higher the fairness of the procedures used by the tax authorities, the more satisfied the taxpayers' feeling with the tax authorities.

Traditional model has some weaknesses because this model treats taxation as an isolated case. Understanding taxpayer compliance is necessary to determine the behavior of other taxpayers. Pro-social behavior theory, which takes the behavior of other people into consideration, may be promising.

On the other hand, social norms theory states that taxpayers are likely to increase their pro-social behavior if there is a stimulus. The taxpayers will seek to adjust their personal interests with the prevailing social norms. Social norms stimulus can be in the form of fairness, cooperation or fulfillment of promise. When there is such stimulus, someone will take higher pro-social action than when there is no such stimulus. This is the following hypotheses: (1) Tax compliance will increase when the taxpayers feel that the tax authorities treat them fairly. (2) Tax compliance will increase when the taxpayers know that other taxpayers also contribute to pay taxes. (3) In circumstances where other taxpayers do not contribute to pay taxes, the taxpayers who feel that they get fair treatment from the tax authorities will fulfill their tax obligations.

\section{Research Design}

\section{METHOD}

Experiment between subjects in this study is using a $2 \times 2$ factorial design. This method involves the manipulation of the condition of the subject studied, with strict control over external factors, and a comparison subjects to establish a causal phenomenon. The experiment used in this research is a laboratory experiment which is conducted to complement other studies of tax compliance mostly done using secondary data. There are two independent variables, in which each variable has two levels. The variables being subjected in this experiment are trust to the tax authorities and perception of the behavior of other taxpayers. The cases contained in this experimental design are taken from real cases that often occur in the community and have a low-detected probability and thus requiring voluntary tax compliance to report it. The process of designing manipulation involves psychologists and taxation experts through focus group discussion.

Two short videos, with duration of five minutes each, were made for the simulation of the tax compliance. The first video is about the high trust to the tax authorities and the second video is about the low trust to the tax authorities. The treatment of the perception of other taxpayers' behavior is provided in the form of storyboards. At the level of other taxpayers who contribute to pay their taxes is given a storyboard containing conversations between the taxpayers and other taxpayers who always report all their income in the tax return. Meanwhile, at the level of other taxpayers who do not contribute to pay their taxes is given a storyboard containing conversations between the taxpayers and other taxpayers who do not report their income received in the tax return.

\section{Participant}

The researcher invited 80 MSME entrepreneurs to participate in a training that was ended with simulation of taxes. The participants who had TIN and passed the manipulation test were 60 people.

\section{Procedure}

Participants were divided into four groups. The division of the group was associated with the treatment that would be received by each participant in accordance with the lottery numbers drawn. Randomization was performed by taking lottery numbers that divided the participants into two groups. Having entered each room, the participants were randomized again to the division of the different booklets so that later the participants were divided into four groups which were equal to the number of cells of this research.

In this simulation, the participants were asked to play as a taxpayer who had a quite advanced restaurant business and was given a case. Then he was given a video treatment about the low/high trust to the tax authorities. After that, the participants were asked to make a decision whether to report all or only partially or not report their income in the tax return. The second treatment was in the form of a storyboard containing conversations between taxpayers and other taxpayers who had reported/had not reported all of their income. Then, the participants were asked to make a decision again whether to report all or only partially or not report their income in the tax return depending on their response to each treatment received. The scale used was from $0 \%$ (not reporting all income) to $100 \%$ (reporting all income).

\section{RESEARCH FINDINGS \& DISCUSSION}

ANOVA test results show that the independent variables of trust to the tax authorities and trust to other taxpayers have an effect on the percentage of income reported, which means that $\mathrm{H}_{1}$ and $\mathrm{H}_{2}$ are accepted. The trust to the tax authorities 
provides $\mathrm{f}$ count value of 90.147 with $\mathrm{P}$ value/significance value $=0.00<$ alpha $=0.05$. This indicates that main effects are supported; meaning that there is a difference in the percentage of income reported between the categories of the trust to the tax authorities. The perception of other taxpayers contributes to increase awareness of the taxpayers in reporting their income taxes than the perception of other taxpayers who do not contribute. It can be seen from the $\mathrm{f}$ count value of 28.688 with $\mathrm{P}$ value/significance value $=0.00<\mathrm{alpha}=0.05$

TABLE 1

Tests of Between-Subjects Effects

Dependent Variable: Percentage of earnings reported

\begin{tabular}{|c|c|c|c|c|c|}
\hline Source & $\begin{array}{l}\text { Type III } \\
\text { Sum of } \\
\text { Squares }\end{array}$ & df & $\begin{array}{c}\text { Mean } \\
\text { Square }\end{array}$ & $\mathrm{F}$ & Sig. \\
\hline $\begin{array}{l}\text { Corrected } \\
\text { Model }\end{array}$ & $48780.878^{a}$ & 3 & 16260.293 & 39.616 & .000 \\
\hline Intercept & 165902.411 & 1 & 165902.411 & 404.195 & .000 \\
\hline Authority & 37000.744 & 1 & 37000.744 & 90.147 & .000 \\
\hline Taxpayer & 11775.030 & 1 & 11775.030 & 28.688 & .000 \\
\hline $\begin{array}{l}\text { Authority * } \\
\text { Taxpayer }\end{array}$ & 90.030 & 1 & 90.030 & .219 & .641 \\
\hline Error & 22985.268 & 56 & 410.451 & & \\
\hline Total & 228081.250 & 60 & & & \\
\hline $\begin{array}{l}\text { Corrected } \\
\text { Total }\end{array}$ & 71766.146 & 59 & & & \\
\hline
\end{tabular}

a. R Squared =,680 (Adjusted R Squared $=, 663$ )

There is no joint effect between the trust to tax authority and the trust to other taxpayers on the percentage of income reported. It can be seen from the results of interaction where the value of $\mathrm{f}$ count is 0219 with a $\mathrm{P}$ value/significance value $=$ $0,641>$ alpha $=0.05$, which means that $\mathrm{H} 3$ is not supported. Adjusted R-squared $=0.663$ or $66.3 \%$ means the variability of the percentage of income reported that can be explained by the variable of trust to the tax authorities, the perception of other taxpayers and the authority interaction with the taxpayers of $69.7 \%$. The following is a graph of the interaction between the trust to the tax authorities and the perception of other taxpayers:

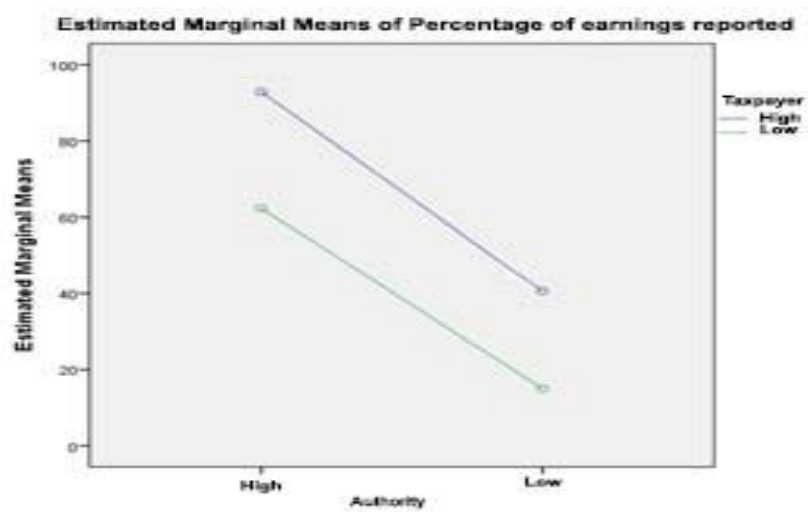

This study examines the effect of public trust to the tax authority and other taxpayers on the decision of voluntary tax compliance in a randomized experimental research. Trust has three essential components[10]. First, the trust that the partners, in the relationship, would show good faith in their actions which may affect the relationship carried out directly and indirectly. Second, the trust also includes honesty, which means that a party entrusts a relationship to a trusted partner. Third, there is a dimension which includes the trust in the competence. It is the trust that the partner, in the relationship, has the ability to act on the basis of the benefits of the relationship. Hypothesis 1 predicts that vertical trust has positive effect on tax compliance. The test results support the prediction. The taxpayers who feel that they are treated properly and fairly by the tax officials will have a high confidence in the tax authorities. This removes the existing stigma that the tax officials always behave arrogantly, suspiciously and arbitrarily to the taxpayers like "cops and robbers". The taxpayers feel that they are served by the tax authorities who refer to a "psychological contract" and respectful relationships that encourage the taxpayers to act loyally and pay taxes honestly. This research complements the research of De Cremer[11], Van Dijke and Verboon[12], Feld and Frey[13], and Kirchler, Hoelzl et al.[14] that the mutual trust between the tax authorities and the taxpayers leads to a synergistic climate. In the synergistic climate, the tax authorities believe that the people pay their taxes honestly, so that the tax authorities treat them politely and respectfully. In the end the taxpayers believe that the government and tax authorities provide good service to them so that the taxpayers meet their tax obligations obediently and truly. The level of procedural fairness is an important resource for the public in evaluating the level of the moral of the tax authorities. The research conducted by Frey and Torgler[15] shows consistent findings that the public perceives the authority that gives unfair procedures of sanction as the authority that has no legitimacy. The perception of unfair procedure can lead to the decreased trust in the authority. When the tax authorities make fair procedure, the public will tend to adhere to the decision of the authorities.

One of the strategic objectives of the Directorate General of Taxation (DJP) is to increase the satisfaction of taxpayers and stakeholders taxation in order to realize a high level of public confidence in the tax service. This is in line with the mandate of Law Number 25 of 2009 on Public Service. For that DJP issued a Guide Service Excellence Directorate General of Taxation. The guide is expected to be a reference for all employees of the DJP in the act and behave in providing good service to the taxpayer. In fact, there are employees who do not follow the guidelines DJP Service Excellence issued. For that need to be considered fundamental rules of procedural fairness, namely:

a. Consistency. Fair procedures should be consistently better than the one to the other or from time to time. Everyone has equal rights and are treated in the same procedure.

b. Minimization of Bias. There are two sources of bias that often arises, namely individual interest and doctrine pro. Therefore, in an effort to minimize this bias, both individual interests and partiality must be avoided.

c. Accurate information. The information required to determine that justice must be an accurate assessment is to be 
based on facts. If the opinion as a basis, it must be delivered by people who really know the problem, and the information presented must be complete.

d. Irreparable. Efforts to fix the error is one of the important objectives of justice should be upheld. Therefore, a fair procedure also contains rules which aim to correct errors or errors that may appear.

e. Representative. The procedure is said to be fair since the beginning of efforts to involve all parties concerned.

f. Ethical. Fair procedures should be based on ethical and moral standards.

Hypothesis 2 predicts that horizontal trust has positive effect on voluntary tax compliance. The test results of empirical data support this hypothesis. These findings support the theory of reciprocity[16]. Adapted to the context of tax compliance, horizontal reciprocal means that if many people pay taxes, other taxpayers will also feel obligated to contribute and pay taxes. The individuals want their behavior in accordance with normal behavior. Conformity is someone who is willing to contribute to a public good that does not benefit anyone directly, as long as he observes that others contribute sufficiently[17]. Taxpayers are willing to pay their taxes with the requirements depending on the pro-social behavior of other taxpayers. Therefore, when a taxpayer considers that there are more other taxpayers who are honest in paying their taxes, he is also more willing to pay his own taxes. Henrich[18] provides an overview of other promising concept, that is, conformity. Conformity means that the motivation to behave in a conditional cooperation can be influenced by the desire of the taxpayer to meet the social norm to pay taxes and behave according to the rules of society.

Hypothesis 3 states that in a circumstancein which other taxpayers do not contribute to pay taxes, the taxpayers who feel that they have got fair treatment from the tax authorities will fulfill their tax obligations. This hypothesis is not supported by empirical data, which means that this study does not provide evidence that the fair treatment obtained from the authorities can be a stimulant for the taxpayers to contribute to pay taxes even though other taxpayers do not contribute. There are several things that can be used as an explanation. First, there has been no shame culture for not paying taxes in Indonesia. The theory of social norms for tax compliance does not apply in Indonesia. Social norms are common habits that become the standard of behavior in a society and the limitations of certain regions. Norms will develop in line with the social agreements of the community, or commonly called as social rules. Taxpayers in Indonesia do not feel ashamed when they do not pay taxes. A gubernatorial candidate, who formerly worked as a large entrepreneur and has master degree, proudly says that he has succeeded the government programs by following tax amnesty and invites other people to follow in his foot steps. This is done merely to attract public sympathy. Logically, tax amnesty program is a government remission granted to taxpayers who do not report all income earned in previous years. So, it is natural for the taxpayers who are just starting a business because they do not know or have not been able to pay the tax consultant. But for the owners of large companies, they usually hire employees who understand taxation and ensure the correctness of the tax return report using the services of a tax consultant. Therefore, there is no reason for large entrepreneurs to say that they do not know if there are tax, income and property that have not been reported.

Second, there is lack of tax socialization and education in schools. Self assessment system adopted by Indonesia assumes that the taxpayers have already had sufficient knowledge of taxation. A taxpayer of Bachelor graduate majoring in architectural engineering never gets tax education in school. When he starts his business, he, as the taxpayer, must actively seek out by himself. So, it is natural if the taxpayer still has a lack of awareness in paying taxes. Tax education is highly required so that the people know the benefits and functions of taxes earlier. In addition, the people also need to know the different types of taxes and who performs tax collection. Finally, factor of fairness among taxpayers is very influential. For a taxpayer who dutifully pays taxes and fulfills all of his business licensing requirements, tax and business licenses are burdensome. Tax and license fees will affect the businessmen in determining the selling price compared to other businessmen who do not pay taxes and run illegal businesses. The selling price determined by the businessmen who obey to pay taxes cannot compete with the price selling price determined by those who do not obey to pay taxes.

\section{IV.CONCLUSION}

This study of tax compliance divides the trust into two types: vertical trust and horizontal trust. The results of this study explain that trust is an important factor in voluntary tax compliance. The trust to the tax authorities is very influential in stimulating tax compliance among citizens. Previous research states that applying fair procedures can improve the trust to what is established by the authorities.

The research findings also strengthen the theory of conformity where taxpayers will contribute more if other taxpayers also pay taxes. In other words, if many people evade taxes, a taxpayer will not feel obliged to pay taxes. Conformity means that the motivation to behave in a conditional cooperation can be influenced by the desire of the taxpayer to meet the social norm, that is, to pay taxes and behave according to the rules of society.

Based on primary data, there is no interaction between vertical trust and horizontal trust. Taxpayers in Indonesia give more attention to the behavior of other taxpayers and the lack of services provided by the tax authorities. This phenomenon occurs because there is has been no social sanction for those who commit tax evasionin society and lack of knowledge of taxation. To overcome this problem, the government should promote tax socialization/tax education ranging from basic education.

This study explores the effect of vertical and horizontal trust on voluntary tax compliance with participants of MSMEs taxpayersonly. Therefore, there are still large opportunities for further studies to conduct in-depth exploration. The next studies may test the effect of authority trust, authority power 
and horizontal trust partially or simultaneously on tax compliance by using different cases of material.

\section{REFERENCES}

[1] Madeo, Silvia A., et al. Sommerfeld's concepts of taxation. Houghton Mifflin Harcourt School, 1994.

[2] Allingham, Michael G., and Agnar Sandmo. "Income tax evasion: a theoretical analysis." Journal of Public Economics 1.3-4 (1972): 323338.

[3] Keller, Carl Edward. "An experimental investigation of how ethical orientations, tax rates, penalty rates, and audit rates affect tax compliance decisions." (1997).

[4] Alm, James, Gary H. McClelland, and William D. Schulze. "Why do people pay taxes?." Journal of public Economics 48.1 (1992): 2138. Asnawi, Meinarni. "The impact of audit rate, perceived probability of audit on tax compliance decision:(A Laboratory Experiment Study)." Journal of Indonesian Economy and Business: JIEB. 28.2 (2013): 292.

[5] Hays, Stanley Wayne. An empirical analysis of taxpayers' attitudes and behavioral intentions regarding compliance with federal income tax laws. Diss. Louisiana Tech University, 2000.

[6] Chung, Janne, and Vaswanath Umashanker Trivedi. "The effect of friendly persuasion and gender on tax comliance behavior." Journal of Business Ethics 47.2 (2003): 133-145.

[7] Alm, James, Betty R. Jackson, and Michael McKee. "Estimating the determinants of taxpayer compliance with experimental data." National Tax Journal (1992): 107-114

[8] Mendoza Rodriguez, J. P., and J. L. Wielhouwer. "Only the Carrot, Not the Stick: Incorporating Trust into the Enforcement of Regulation." (2015).

[9] Kristiaji, B. Bawono, Toni Febriyanto, and Yanuar F. Abiyunus. "Memahami Ke (tidak) patuhan Pajak." Analysis 3.2 (2013)
[10] Walter, Achim, Thilo A. Mueller, and Gabriele Helfert. "The impact of satisfaction, trust, and relationship value on commitment: Theoretica considerations and empirical results." IMP Conference Proceedings. 2000.

[11] De Cremer, David. "The influence of accuracy as a function of leader's bias: The role of trustworthiness in the psychology of procedural justice." Personality and Social Psychology Bulletin 30.3 (2004): 293 304.Henrich, Joseph. "Cultural group selection, coevolutionary processes and large-scale cooperation." Journal of Economic Behavior \& Organization 53.1 (2004): 3-35.

[12] Van Dijke, Marius, and Peter Verboon. "Trust in authorities as a boundary condition to procedural fairness effects on tax compliance." Journal of Economic Psychology 31.1 (2010): 80-91.

[13] Feld, Lars P., and Bruno S. Frey. "Tax compliance as the result of a psychological tax contract: The role of incentives and responsive regulation."Law \& Policy 29.1 (2007): 102-120.

[14] Kirchler, Erich, Erik Hoelzl, and Ingrid Wahl. "Enforced versus voluntary tax compliance: The "slippery slope" framework." Journal of Economic Psychology 29.2 (2008): 210-225.

[15] Frey, Bruno S., and Benno Torgler. "Tax morale and conditional cooperation." Journal of Comparative Economics 35.1 (2007): 136-159.

[16] Frey, Bruno S., and Benno Torgler. "Tax morale and conditional cooperation." Journal of Comparative Economics 35.1 (2007): 136-159.

[17] Bardsley, Nicholas, and Rupert Sausgruber. "Conformity and reciprocity in public good provision." Journal of Economic Psychology 26.5 (2005) 664-681.Muehlbacher, Stephan, et al. "Uncertainty resolution in tax experiments: Why waiting for an audit increases compliance." The Journal of Socio-Economics41.3 (2012): 289-291.

[18] Henrich, Joseph. "Cultural group selection, coevolutionary processes and large-scale cooperation." Journal of Economic Behavior \& Organization 53.1 (2004): 3-35.van Dijke, Marius, and Peter Verboon. "Trust in authorities as a boundary condition to procedural fairness effects on tax compliance." Journal of Economic Psychology 31.1 (2010): 80-91. 